\title{
Giant Malignant Insulinoma Which Developed from a Non-Functioning Pancreatic Tumor Over a Long Period of Time
}

\author{
Toru Sugiyama ${ }^{1}$, Ryuji Kouyama ${ }^{1}$, Yuji Tani ${ }^{1}$, Hajime Izumiyama ${ }^{1}$, Takumi Akashi ${ }^{2}$, \\ Seiji Kishimoto ${ }^{3}$, Shigeki Arii ${ }^{4}$ and Yukio Hirata ${ }^{1}$
}

\begin{abstract}
Insulinomas are the most common hormone-producing pancreatic neuroendocrine tumors (NETs), which are usually benign, solitary and small. We describe herein a patient with a giant insulinoma $(>10 \mathrm{~cm}$ in diameter) with concomitant thyroid tumor as detected by Somatostatin receptor scintigraphy (SRS). A 50-yearold man presented hypoglycemic symptoms 20 years after the first detection of a pancreatic tumor, which was ameliorated by administration of a somatostatin analogue, octreotide. SRS showed abnormal uptake by the insulinoma as well as by the thyroid tumor. RT-PCR and immunohistochemical study revealed abundant expression of somatostatin receptor (SSTR)-1, -2, and -5 in his insulinoma and SSTR-1 and -2 in his thyroid follicular neoplasm. This is a rare case of a slow-growing pancreatic well-differentiated neuroendocrine carcinoma over a long period of time to become a symptomatic giant insulinoma. Furthermore, SRS proves to be a useful tool for localization of insulinoma as well as concomitant thyroid neoplasm with predominant expression of SSTRs.
\end{abstract}

Key words: insulinoma, somatostatin receptor, somatostatin receptor scintigraphy, octreotide, thyroid follicular neoplasm, neuroendocrine tumor

(Inter Med 49: 1573-1579, 2010)

(DOI: 10.2169/internalmedicine.49.3540)

\section{Introduction}

Insulinomas are rare but are the most common hormoneproducing pancreatic neuroendocrine tumors (NETs) with an incidence estimated at four cases per million annually (1). The main clinical manifestation is hypoglycemia secondary to inappropriate insulin hypersecretion and, in a minority (< $10 \%)$ of cases, tumoral progression due to malignant transformation. Multiple insulinomas are observed in about $10 \%$ of cases, usually in patients presenting multiple endocrine neoplasia type 1 (MEN1) $(1,2)$. Although octreotide, a somatostatin analogue, has been widely used in the symptomatic treatment of patients with pancreatic NETs (3), sur- gery remains the only curative treatment in localized insulinomas. However, the preoperative localization of the insulinoma is often difficult if the tumor is small; it has been reported that $24 \%$ of insulinomas are less than $1 \mathrm{~cm}, 42 \%$ are $1-2 \mathrm{~cm}$, and $30 \%$ are $2-3 \mathrm{~cm}$ in diameter (4-6). It is also important to examine the whole body for multiple neoplasia or metastasis since $5-10 \%$ of insulinomas are malignant (7). Somatostatin receptor scintigraphy (SRS) has been shown to be useful for the visualization of NETs with positive somatostatin receptors (SSTR) to detect not only the primary tumor, but also metastasis (8-10). We encountered a patient with a malignant insulinoma who had a long period of asymptomatic state until the tumor became huge. His hypoglycemia was ameliorated by the administration of octreotide

\footnotetext{
${ }^{1}$ Department of Clinical and Molecular Endocrinology, Tokyo Medical and Dental University Graduate School, Tokyo, ${ }^{2}$ Department of Pathology, Tokyo Medical and Dental University Graduate School, Tokyo, ${ }^{3}$ Department of Head and Neck Surgery, Tokyo Medical and Dental University Graduate School, Tokyo and ${ }^{4}$ Department of Hepato-Biliary-Pancreatic Surgery, Tokyo Medical and Dental University Graduate School, Tokyo

Received for publication February 16, 2010; Accepted for publication April 19, 2010

Correspondence to Dr. Toru Sugiyama, tsugiyama.cme@tmd.ac.jp
} 
Table 1. PCR Primers Used for RT-PCR

\begin{tabular}{|c|c|c|c|}
\hline Primers & & Sequences & $\begin{array}{c}\text { PCR } \\
\text { product size }\end{array}$ \\
\hline SSTR-1 & $\begin{array}{l}\text { Forward } \\
\text { Reverse }\end{array}$ & $\begin{array}{l}\text { 5'-AGACGGCCACCAACATCTAC-3' } \\
\text { 5'-GCACGTAGCACAGGCAGATA-3' }\end{array}$ & $450 \mathrm{bp}$ \\
\hline SSTR-2 & $\begin{array}{l}\text { Forward } \\
\text { Reverse }\end{array}$ & $\begin{array}{l}\text { 5'-GACAAGCAATGCAGTCCTCA-3' } \\
5^{\prime} \text {-CTGTGTACCAAGCCCCAGAT-3' }\end{array}$ & $500 \mathrm{bp}$ \\
\hline SSTR-3 & $\begin{array}{l}\text { Forward } \\
\text { Reverse }\end{array}$ & $\begin{array}{l}\text { 5' -TCTGCTACCTGCTCATCGTG-3' } \\
\text { 5' }^{\prime} \text { TTGAAGCGGTAGGAGAGGAA-3' }\end{array}$ & $290 \mathrm{bp}$ \\
\hline SSTR-4 & $\begin{array}{l}\text { Forward } \\
\text { Reverse }\end{array}$ & 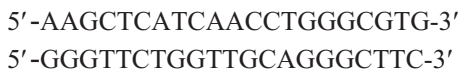 & $635 \mathrm{bp}$ \\
\hline SSTR-5 & $\begin{array}{l}\text { Forward } \\
\text { Reverse }\end{array}$ & 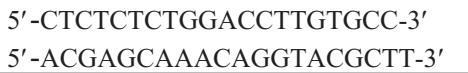 & $310 \mathrm{bp}$ \\
\hline
\end{tabular}

and SRS revealed preferential increased radioactive uptakes by the insulinoma as well as by the concomitant thyroid tumor, which was confirmed by the predominate expression of SSTRs, as demonstrated by RT-PCR and immunohistochemical study.

\section{Methods}

\section{Reverse transcriptase-polymerase chain reaction (RT-PCR)}

Total RNA was extracted from the resected tissue of insulinoma or thyroid tumor using RNA zol (GIBCO/BRL, Carlsbad, CA), and cDNA synthesized using a First-Strand cDNA Syntheses Kit (Amersham Pharmacia Biotech Inc., Piscataway, NJ) according to the manufacturer's instructions. PCR primers of human SSTR 1-5 designed in an earlier report (11) were synthesized by Greiner Bio-One (Tokyo, Japan), and their sequences are shown in Table 1. The PCR products were examined by $1.5 \%$ agarose gel electrophoresis.

\section{Immunohistochemical study}

Immunohistochemical staining was performed on formalin-fixed, paraffine-embedded specimens of resected tumor samples by the avidin-biotin-peroxidase complex (ABC) method using an auto-staining machine (Ventana Benchmark HX System, Ventana Medical System, Tucson, AZ, USA), according to the manufacturer's protocols. Antibodies used in this study were mouse monoclonal antibody against human insulin (1:1 dilution, Nichirei), rabbit polyclonal antibody against human chromogranin A (1:1,000 dilution, DAKO), rabbit polyclonal antibody against human synaptophysin (1:50 dilution, DAKO), and rabbit polyclonal antibody against human SSTR-2A (1:1,600 dilution, Gramsch Laboratories, Schwabhausen, Germany).

\section{Ethics}

This study was approved by the Ethics Committee of Tokyo Medical and Dental University Hospital; written in- formed consent was obtained from the patient.

\section{Case Report}

A 50-year-old man was brought to the emergency room of our hospital because of unconsciousness. He was found to have hypoglycemia $(41 \mathrm{mg} / \mathrm{dL})$, and recovered from unconsciousness after intravenous administration of $50 \%$ glucose. Twenty-one years previously, he was incidentally found to have a $5 \mathrm{~cm}$ pancreatic tumor by an abdominal ultrasonography at a regular health checkup. The tumor was considered as a benign non-functioning cystic adenoma due to the lack of tendency for progression evaluated by computed tomography (CT) scans without any abnormal physical and laboratory findings. Annual health checkups had revealed slight hypoglycemia $(<70 \mathrm{mg} / \mathrm{dL})$ for the last 4 years. In the previous 3 months, he had noticed feelings of discomfort with excessive sweating during fasting. His family history and past history were unremarkable.

On admission, he was $181 \mathrm{~cm}$ tall and weighted $74.5 \mathrm{~kg}$. Physical and neurological examinations revealed no abnormal findings and normal vital signs. Endocrine examinations excluded hypopituitarism (plasma ACTH $91 \mathrm{pg} / \mathrm{mL}$ ), adrenal insufficiency (serum cortisol $17.8 \mu \mathrm{g} / \mathrm{dL}$ ), hepatic failure (AST 25 IU/L, ALT 18 IU/L), and insulin autoimmune syndrome (anti-insulin antibody $8.4 \%$; normal $<10 \%$ ) as the cause of his hypoglycemia. A 4-hour fast reproduced his hypoglycemic symptoms with low plasma glucose $(41 \mathrm{mg} / \mathrm{dL})$ associated with inappropriate elevations of immunoreactive insulin (IRI; $8.6 \mu \mathrm{U} / \mathrm{mL}$ ) and C-peptide (2.8 ng/mL). Tumor markers such as DUPAN-2 $(850 \mathrm{U} / \mathrm{mL}$; normal <150), NSE $(56 \mathrm{ng} / \mathrm{mL}$; normal <10), and thyroglobulin $(1,000 \mathrm{ng} / \mathrm{mL}$; normal <30) were elevated (Table 2). Contrast CT scan of the abdomen revealed a large lobulated mass $(10.7 \times 6.5 \mathrm{~cm})$ with heterogeneous enhancement in the pancreatic head (Fig. 1). ${ }^{18}$ F-fluorodeoxyglucose (FDG) positron emission tomography (PET) imaging showed increased uptakes of FDG in the regions of pancreas and right anterior neck (Fig. 2). SRS showed increased uptakes of ${ }^{111}$ In-pentetreotide around the pancreas, the right anterior neck, and the right mediasti- 
Table 2. Tumor Markers and Endocrine Data

\begin{tabular}{llr}
\hline & Pre Op & Post Op \\
Tumor markers & & \\
DUPAN-2 & $850 \mathrm{U} / \mathrm{mL}$ & $<25 \mathrm{U} / \mathrm{mL}$ \\
NSE & $56 \mathrm{ng} / \mathrm{mL}$ & $2.4 \mathrm{ng} / \mathrm{mL}$ \\
CA19-9 & $5.5 \mathrm{U} / \mathrm{mL}$ & \\
Elastase-1 & $390 \mathrm{ng} / \mathrm{dL}$ & \\
ProGRP & $19.1 \mathrm{pg} / \mathrm{mL}$ & \\
& & \\
Endocrine Data & & \\
Insulin & $8.6 \mu \mathrm{UU} / \mathrm{mL}$ & $1.9 \mu \mathrm{U} / \mathrm{mL}$ \\
C-peptide & $2.8 \mathrm{ng} / \mathrm{mL}$ & $0.7 \mathrm{ng} / \mathrm{mL}$ \\
Glucagon & $145 \mathrm{pg} / \mathrm{mL}$ & \\
Gastrin & $73 \mathrm{pg} / \mathrm{mL}$ & \\
intact PTH & $49 \mathrm{pg} / \mathrm{mL}$ & \\
GH & $0.32 \mathrm{ng} / \mathrm{mL}$ & \\
IGF-1 & $129 \mathrm{ng} / \mathrm{mL}$ & \\
PRL & $6.7 \mathrm{ng} / \mathrm{mL}$ & \\
ACTH & $91 \mathrm{pg} / \mathrm{mL}$ & \\
Cortisol & $17.8 \mu \mathrm{gg} / \mathrm{dL}$ & \\
LH & $1.0 \mathrm{mIU} / \mathrm{mL}$ & \\
FSH & $5.8 \mathrm{mIU} / \mathrm{mL}$ & \\
TSH & $1.02 \mu \mathrm{IU} / \mathrm{mL}$ & \\
FT3 & $2.81 \mathrm{pg} / \mathrm{mL}$ & \\
FT4 & $1.35 \mathrm{ng} / \mathrm{dL}$ & \\
Thyroglobulin & $1000 \mathrm{ng} / \mathrm{mL}$ & $13.3 \mathrm{ng} / \mathrm{mL}$ \\
\hline Abbreviation: Op: operation &
\end{tabular}

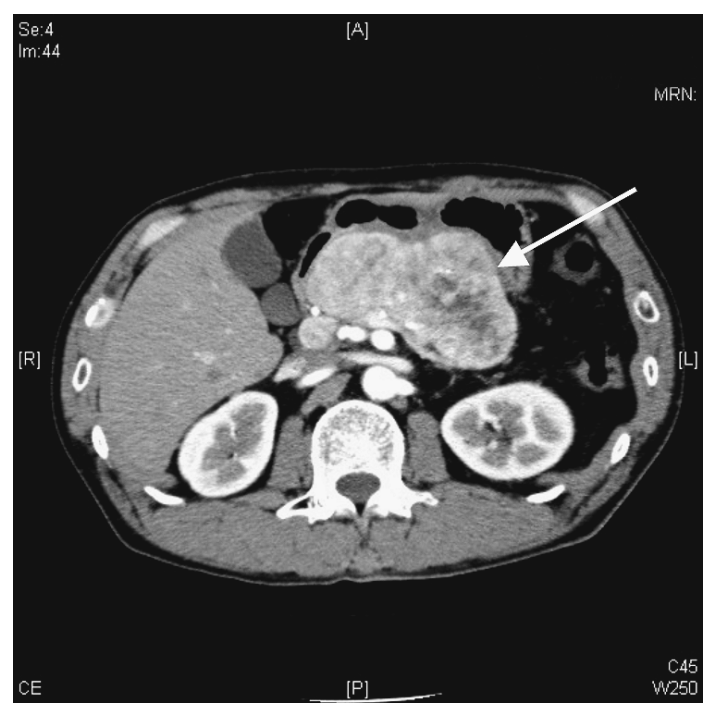

Figure 1. Abdominal CT scan. Arrow indicates a huge lobulated mass $(10.7 \times 6.5 \mathrm{~cm})$ with heterogeneous enhancement in the pancreatic body.

num (the hilar area and the paravertebral area) (Fig. 3), whereas neither CT scanning nor FDG-PET revealed any abnormalities in the chest regions and the mediastinum.

Administration of octreotide (300 $\mu \mathrm{g}$ per day) was effective in elevating his plasma glucose levels under the continuous intravenous infusion of glucose ( $4 \mathrm{~g} /$ hour). Based on the diagnosis of insulinoma localized in the pancreatic head, pancreatoduodenectomy was performed. The resected tumor $(12 \times 6 \times 4.5 \mathrm{~cm})$ was pathologically diagnosed as an insulinoma with local invasion to the surrounding adipose tissue, which was classified as a well differentiated endocrine carcinoma (low grade malignancy with gross local invasion and/ or metastases) according to the 2000 WHO Classification for pancreatic endocrine neoplasms. As shown in Fig. 4, im-

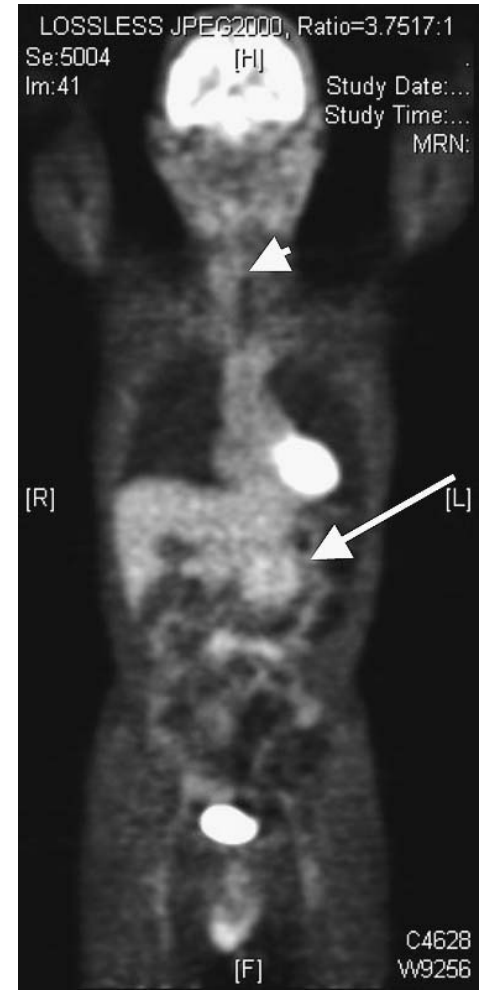

Figure 2. FDG-PET. Arrows indicate abnormal uptakes in the right anterior neck (short arrow) and the pancreas (long arrow).

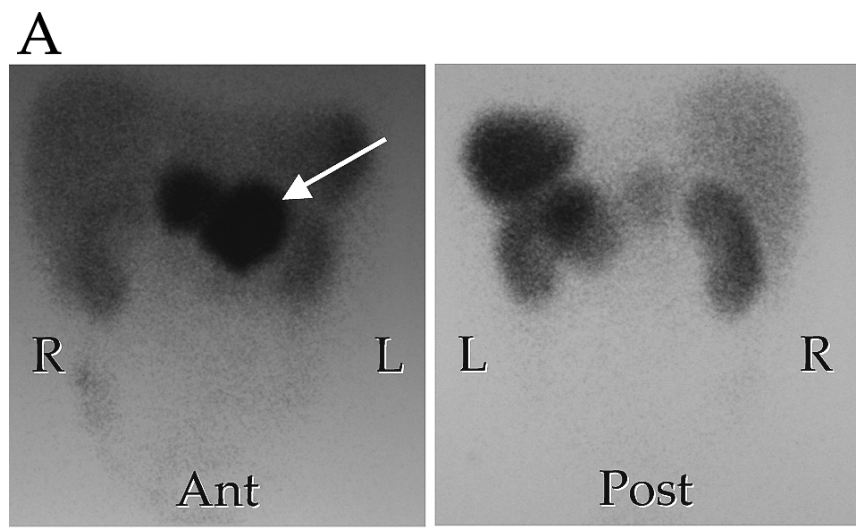

B

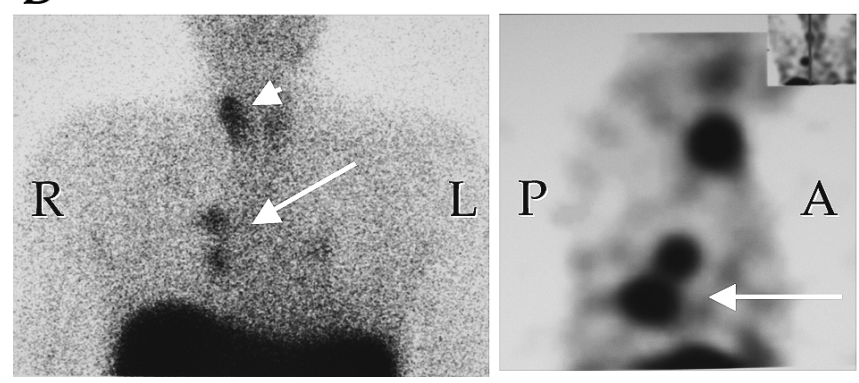

Figure 3. Somatostatin receptor scintigraphy (111 Inpentetreotide). Arrows indicate abnormal uptakes in the pancreas (A), the right anterior neck (short arrow in $B$ ), and the right mediastinum (long arrows in B).

munohistochemical study showed positive staining for insulin, chromogranin A, synaptophysin, SSTR subtype 2A, but 


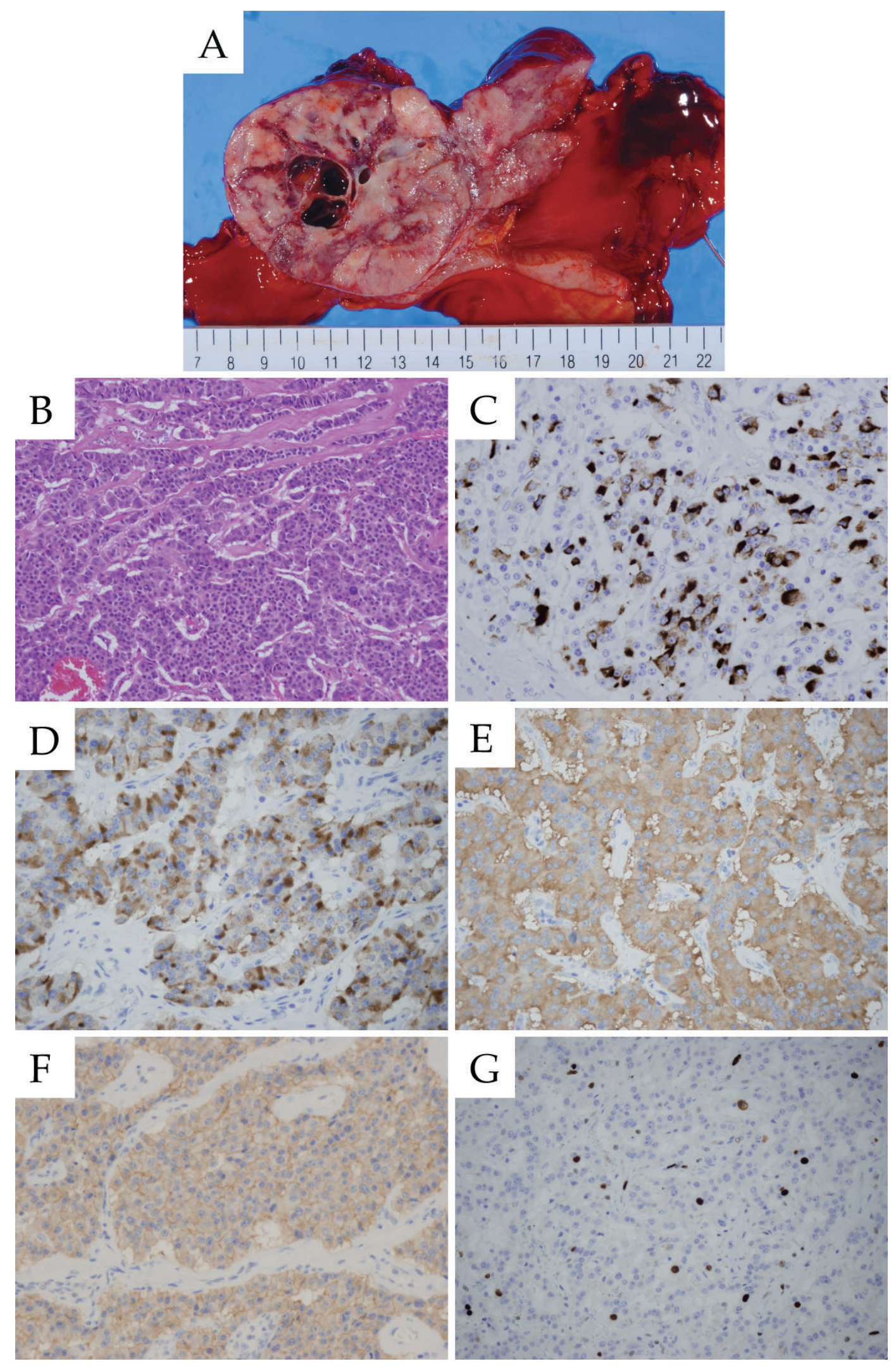

Figure 4. Histology of resected pancreatic tumor. (A) Gross appearance of tumor $(12 \times 6 \times 4.5 \mathrm{~cm})$. (B) Microscopic appearance (Hematoxylin and Eosin staining, $\times 100)$. Immunostaining for $(C)$ insulin (×200), (D) chromogranin A $(\times 200)$, (E) synaptophysin $(\times 200)$, (F) SSTR-2A $(\times 200)$, and (G) Ki$67(\times 200)$.

negative for glucagon and gastrin (data not shown). The specimen displayed 1-2\% Ki-67-positive cells and $<1$ mitosis per ten high power fields. RT-PCR clearly showed pref- erential expression of SSTR subtype 1, 2, and 5 with the resected tumor (Fig. 5A).

Postoperatively, his hypoglycemic episode subsided with 

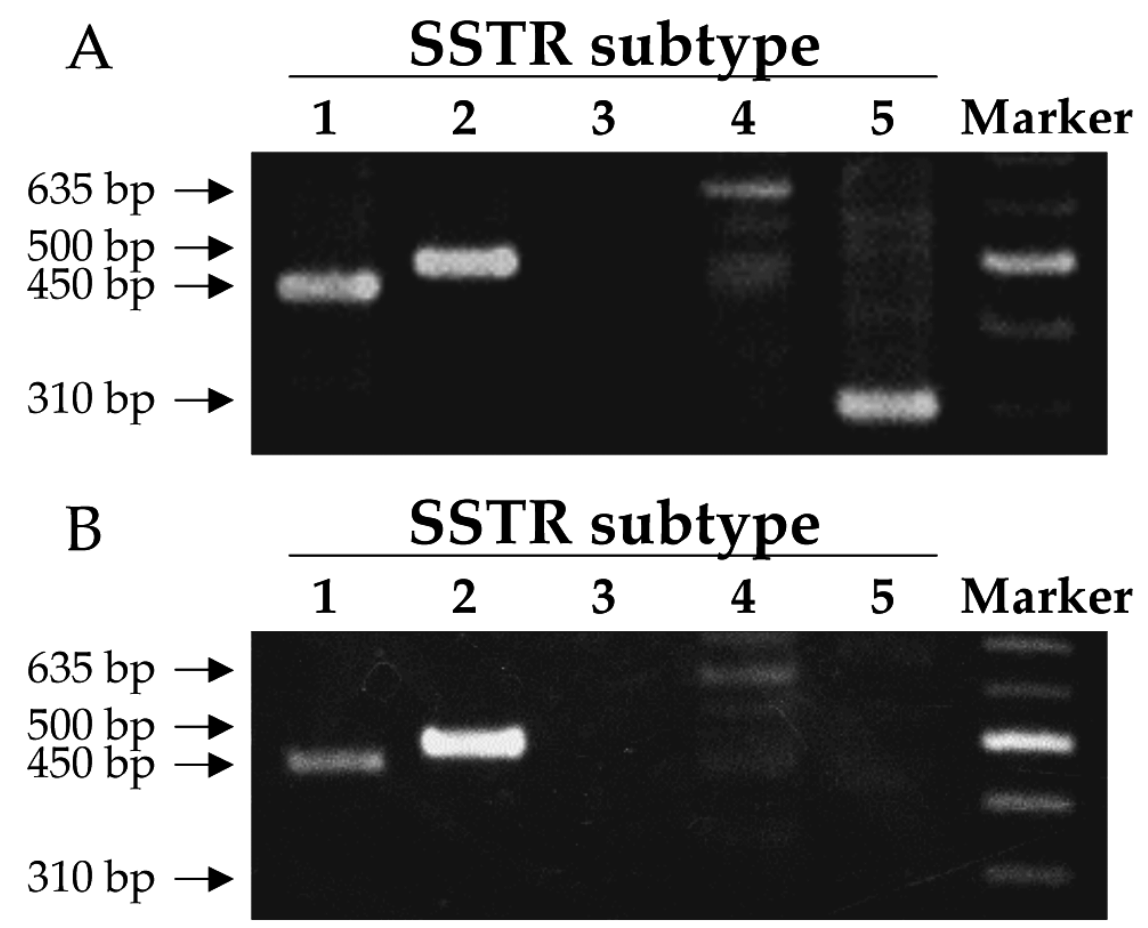

Figure 5. Gene expressions of SSTR subtype 1-5 in the pancreatic tumor (A) and in the thyroid tumor (B). RT-PCR of the patient' s tumor tissues revealed distinct bands on $1.5 \%$ agarose gel electrophoresis, representing the indicated subtypes of SSTR.
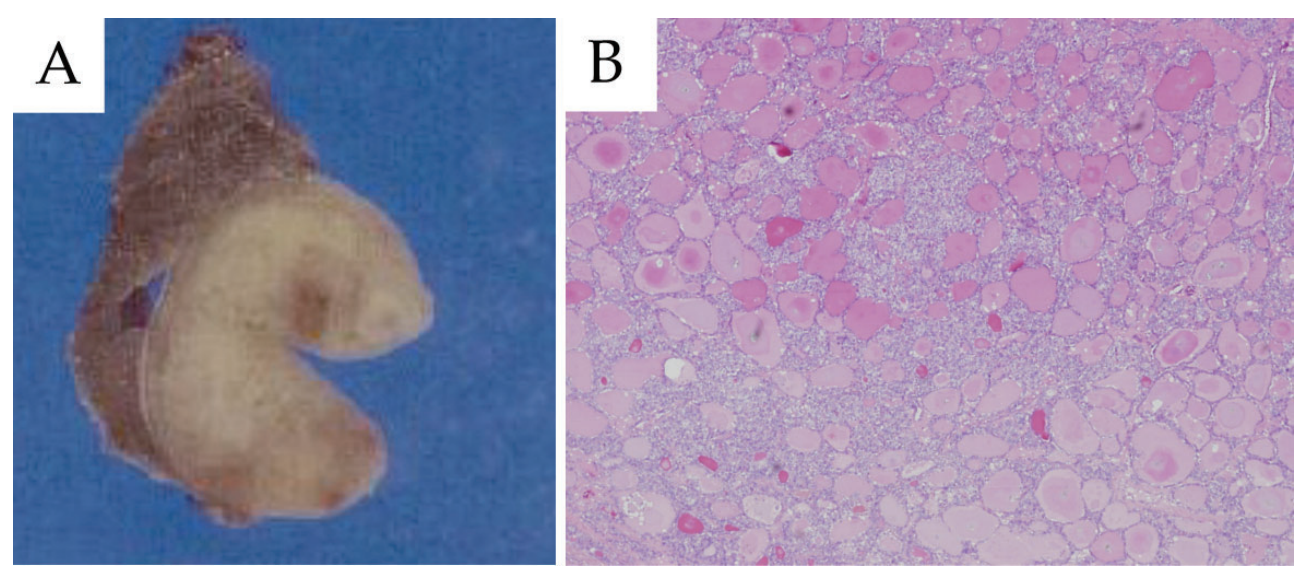

Figure 6. Histology of resected thyroid tumor. (A) Gross appearance of tumor $(21 \times 17 \times 32 \mathrm{~mm})$. (B) Microscopic appearance with hyperplastic microfollicles and normofollicules (Hematoxylin and Eosin staining, $\times 100$ ).

normalization of insulin as well as other tumor markers (DUPAN-2, NSE) (Table 2). Ultrasonography of the neck revealed a solid tumor (20 $\mathrm{mm}$ in diameter) in the right lobe of the thyroid gland, consistent with the increased uptake area on SRS and FDG-PET. Fine needle aspiration biopsy was suggestive of a follicular thyroid neoplasm, and right thyroid lobectomy was performed; the resected tumor (21x $17 \times 32 \mathrm{~mm}$ ) was diagnosed as a follicular neoplasm of undeterminate malignant behavior, consisting of hyperplastic microfollicles and normofollicules, without capsular invasion or angioinvasion by tumor cells (Fig. 6). Immunohistochemical study showed positive staining for SSTR subtype 2 A (data not shown), and RT-PCR clearly showed preferential expression of SSTR subtypes 1 and 2 with the resected tumor (Fig. 5B). Postoperatively, the thyroglobulin level decreased from $1,570 \mathrm{ng} / \mathrm{mL}$ to $13.3 \mathrm{ng} / \mathrm{mL}$ (Table 2). Imaging tests including chest CT scan, magnetic resonance imaging (MRI), gallium scintigraphy, and FDG-PET did not detect any abnormal lesions in the mediastinum.

\section{Discussion}

Insulinoma is the most common cause of hyperinsulinemic hypoglycemia in the adult population as diagnosed by Whipple's triad: symptoms and signs of hypoglycemia, low plasma glucose level, and reversal of hypoglycemic symp- 
toms after glucose administration $(12,13)$. Most insulinomas are small (less than $2 \mathrm{~cm}$ ) at the time of diagnosis since they are generally slow-growing tumors, which often present with the hypoglycemic symptoms secondary to inappropriate insulin secretion even when the tumor is small (4-6). The majority of patients with insulinomas have a tumor size of 1-2 cm, with $96 \%$ less than $3 \mathrm{~cm}$ (4-6). The mean tumor size of insulinomas has been reported to be $1.5 \mathrm{~cm}$, with a wide range of $0.1-7.0 \mathrm{~cm}$ (14-16), while tumors larger than $3 \mathrm{~cm}$ raise concern for malignancy. In a review of malignant insulinomas (17), the average tumor size of 14 cases was $4.7 \pm 0.6 \mathrm{~cm} ; 11$ cases had a tumor size of more than $3 \mathrm{~cm}$ in diameter, including 2 cases with $7.0 \mathrm{~cm}$ and one case with $9.0 \mathrm{~cm}$. Additional review of the world literature identified only 4 cases of insulinomas more than $9 \mathrm{~cm}$ in size $(6,18-20)$. Thus, the present case with a $12 \mathrm{~cm}$ tumor size is considered to be an exceptionally giant insulinoma thus far reported.

It should also be noted that the functioning neuroendocrine carcinoma developed from a 'non-functioning' pancreatic tumor over a long period of time in the present case. Since insulin-positive cells were relatively few in the tumor by immunohistochemical analysis, it is possible to speculate that the tumor grew very slowly over 20 years and insulin secretion from the tumor was insufficient to cause distinct hypoglycemic symptoms.

SRS using ${ }^{111}$ In-pentetreotide, although not currently available in Japan, is widely used to localize NET in Europe and USA since many NETs express SSTR (8-10). There are five known SSTR subtypes, all of which may be expressed by pancreatic NETs. However, SSTR-2 predominates, with more than $80 \%$ of tumors expressing this subtype $(21,22)$. Since octreotide binds with high affinity to both SSTR-2 and SSTR-5 (3), SRS can detect small tumors below the detection limit of conventional radiological imaging techniques, and also survey the whole body for multiple neoplasm or metastasis. These technical advantages led us to survey the whole body by SRS in the present case due to the possible malignant nature of such a giant insulinoma.

The sensitivity of SRS for the detection of pancreatic NETs including gastrinoma, glucagonoma, and nonfunctioning tumors varies between 75 and $100 \%$ (10). In contrast to these NETs, only $50 \%$ of insulinomas express SSTR-2 and the use of SRS in localizing these tumors is often limited $(10,23)$. In the present case, the administration of octreotide successfully reduced insulin hypersecretion to raise plasma glucose levels, suggesting the presence of SSTR-2 and/or SSTR-5 in the insulinoma. In fact, the tissue of resected insulinoma in the present study expressed SSTR-1, SSTR-2 and SSTR-5 mRNA more abundantly than SSTR-3 and SSTR-4 as demonstrated by RT-PCR, which was confirmed by immunohistochemical study. Therefore, effectiveness of octreotide to control blood glucose may predict the usefulness of SRS in localization of insulinomas, including multiple neoplasia and metastasis.

The abnormal uptake of ${ }^{111}$ In-pentetreotide in the right an- terior neck by SRS in the present case was consistent with the diagnosis of thyroid follicular neoplasm with expression of SSTR-1 and -2 as demonstrated by RT-PCR and immunohistochemical study, which is compatible with the literature reporting that thyroid follicular neoplasms often express SSTR-2 (24). However, it remains unknown whether there is any linkage between the insulinoma and the thyroid follicular neoplasm in the present case according to the pathological study and gene expressions of SSTRs evaluated by RTPCR. It is possible to speculate that excess insulin may promote the growth of the thyroid follicles by interacting with the receptor for insulin-like growth factor-1 (IGF-1), a potent mitogenic growth factor, to induce tumor growth $(25,26)$. In fact, hyperinsulinemia associated with insulin resistance in cases with metabolic syndrome has been reported to significantly increase thyroid volume and nodule prevalence (27), although there has been no epidemiological study showing a higher occurrence of thyroid tumors in patients with insulinoma. In addition, the present case is unlikely to have MEN1 because he had no tumor detected in parathyroid or pituitary nor family history.

SRS in the present case also showed the abnormal uptake in the right mediastinum region. Since abnormality has not been detected by any other imaging modalities including chest CT scan, MRI, gallium scintigraphy, or FDG-PET, it is possible to suspect it may represent a very small metastasis to the mediastinum from the insulinoma and/or the thyroid follicular neoplasm. However, metastasis from the thyroid follicular neoplasm could be ruled out because the thyroglobulin levels were normalized after complete resection of the thyroid tumor. Since neither CT scan nor FDG-PET performed one year after surgery revealed any abnormality along with the normal plasma glucose and insulin levels. Thus, the uptake of ${ }^{111}$ In-pentetreotide in the right mediastinum in the present case may reflect non-specific uptake, such as in inflammatory and/or granulomatous lesion. However, we cannot exclude the possibility that a metastatic lesion may be too small to be detected by imaging tests other than SRS because we had a case with ectopic ACTHproducing pancreatic neuroendocrine tumor with multiple mediastinal lymph nodes metastases that could be detected by SRS, but not by chest CT scan (28). Thus, the present patient needs to be thoroughly followed-up by regular measurements of tumor markers and imaging tests.

\section{Acknowledgement}

This study was supported in part by the Grant-in-aid from the Ministry of Education, Science, Sports and Culture, and the Ministry of Health, Welfare and Labor of Japan. 


\section{References}

1. Service FJ, McMahon MM, O'Brien PC, Ballard DJ. Functioning insulinoma-incidence, recurrence, and long-term survival of patients: a 60-year study. Mayo Clin Proc 66: 711-719, 1991.

2. Boukhman MP, Karam JM, Shaver J, Sipperstein AE, DeLorimeier AA, Clark OH. Localization of insulinomas. Arch Surg 134: 818-822, 1999.

3. Lamberts SW, van der Lely AJ, de Herder WW, Hofland LJ. Octreotide. N Engl J Med 334: 246-254, 1996.

4. Pasieka JL, McLeod MK, Thompson NW, Burney RE. Surgical approach to insulinomas: assessing the need for preoperative localization. Arch Surg 127: 442-447, 1992.

5. Perry RR, Vinik AI. Diagnosis and management of functioning islet cell tumors. J Clin Endocrinol Metab 80: 2273-2278, 1995.

6. Mittendorf EA, Liu YC, McHenry CR. Giant insulinoma: case report and review of the literature. J Clin Endocrinol Metab 90: 575-580, 2005.

7. Hirshberg B, Cochran C, Skarulis MC, et al. Malignant insulinoma: spectrum of unusual clinical features. Cancer 104: 264-272, 2005.

8. Cimitan M, Buonadonna A, Cannizzaro R, et al. Somatostatin receptor scintigraphy versus chromogranin A assay in the management of patients with neuroendocrine tumors of different types: clinical role. Ann Oncol 14: 1135-1141, 2003.

9. Reubi JC. Somatostatin and other peptide receptors as tools for tumor diagnosis and treatment. Neuroendocrinology 80 (Suppl 1): 51-56, 2004.

10. de Herder WW, Kwekkeboom DJ, Feelders RA, et al. Somatostatin receptor imaging for neuroendocrine tumors. Pituitary 9: 243248, 2006.

11. Kondo $\mathrm{T}$, Matsuyama $\mathrm{R}$, Ashihara $\mathrm{H}$, et al. A case of ectopic adrenocorticotropic hormone-producing pancreatic neuroendocrine tumor with multiple liver metastases. Endocr J 57: 229-236, 2010.

12. Service FJ. Hypoglycemic disorders. N Engl J Med 332: 1144 1152, 1995

13. Service FJ. Diagnostic approach to adults with hypoglycemic disorders. Endocrinol Metab Clin North Am 28: 519-532, 2000.

14. Grant CS. Surgical aspects of hyperinsulinemic hypoglycemia. Endocrinol Metab Clin North Am 28: 533-554, 1999.

15. Doherty GM, Doppman JL, Shawker TH, et al. Results of a prospective strategy to diagnose, localize, and resect insulinomas. Surgery 110: 989-997, 1991.
16. Thompson NW, Czako PF, Fritts LL, et al. Role of endoscopic ultrasonography in the localization of insulinomas and gastrinomas. Surgery 116: 1131-1138, 1994.

17. Danforth DN, Gorden P, Brennan MF. Metastatic insulin-secreting carcinoma of the pancreas: clinical course and the role of surgery. Surgery 96: 1027-1036, 1984.

18. Arensman RM, Glassfor GH. Giant insulinoma. Am J Surg 131: 603-604, 1976.

19. Kataoka H, Otsuka F, Yamauchi T, et al. Giant insulinoma in a patient with multiple endocrine neoplasia type I: a case report. Endocr J 46: 429-435, 1999.

20. Marrano D, Campione O, Santini D, Piva P, Alberghini M, Casadei R. Cystic insulinoma: a rare islet cell tumor of the pancreas. Eur J Surg 160: 519-522, 1994.

21. Reubi JC, Kvols L, Krenning E, Lamberts SW. Distribution of somatostatin receptors in normal and tumor tissue. Metabolism 39 (Suppl 2): 78-81, 1990.

22. Oberg K, Kvols L, Caplin M, et al. Consensus report on the use of somatostatin analogs for the management of neuroendocrine tumors of the gastroenteropancreatic system. Ann Oncol 15: 966973, 2004.

23. Lamberts SW, Krenning EP, Reubi JC. The role of somatostatin and its anaglogs in the diagnosis and treatment of tumors. Endocr Rev 12: 450-482, 1991.

24. Druckenthaner M, Schwarzer C, Ensinger C, et al. Evidence for Somatostatin receptor-2 in thyroid tissue. Regul Pept 138: 32-39, 2007.

25. Volzke H, Friedrich N, Schipf S, et al. Association between serum insulin-like growth factor-I levels and thyroid disorders in a population-based study. J Clin Endocrinol Metab 92: 4039-4045, 2007.

26. Sekizawa N, Hayakawa E, Tsuchiya K, et al. Acromegaly associated with multiple tumors. Intern Med 48: 1273-1278, 2009.

27. Ayturk S, Gursoy A, Kut A, Anil C, Nar A, Tutuncu NB. Metabolic syndrome and its components are associated with increased thyroid volume and nodule prevalence in a mild-to-moderate iodine-deficient area. Eur J Endocrinol 161: 599-605, 2009.

28. Doi M, Imai T, Shichiri M, et al. Octreotide-sensitive ectopic ACTH production by islet cell carcinoma with multiple liver metastases. Endocr J 50: 135-143, 2003.
(C) 2010 The Japanese Society of Internal Medicine http://www.naika.or.jp/imindex.html 